\title{
Biografska bilješka
}

Igor Fisković rođen je u Orebićima na Pelješcu 23. travnja 1944. u staroj kući pomoraca koja je, ambijentalno uređena s vrtom, kao cjelovito kulturno-povijesno dobro pod zaštitom države. Majka Linda mu je učila slikarstvo, a otac Cvito bio najistaknutiji hrvatski povjesničar umjetnosti i četrdesetak godina voditelj Instituta za zaštitu spomenika Dalmacije. I ambijent u kojem je boravio, kao i intelektualno okruženje, duboko su obilježili znanstvenu karijeru Igora Fiskovića.

Igor Fisković je u Splitu završio Klasičnu gimnaziju a u Zagrebu 1968. studije povijest umjetnosti i arheologije, te 1975. doktorirao na Filozofskom fakultetu. Od 1970. zaposlen je na Odsjeku za povijest umjetnosti gdje prolazi sve stupnjeve napredovanja, od zvanja izvanrednog profesora 1979. znanstvenog savjetnika 1984., do redovitog profesora 1985. godine. U početku njegove karijere na fakultetu su bili okupljeni vodeći autoriteti humanističkih disciplina Milan Prelog, Grgo Gamulin, Vera Horvat Pintarić, ključni za formiranje najzrelije faze razvoja studija, i u metodološkom pogledu svakako obilježili čitavu generaciju kojoj je Igor Fisković pripadao.

$\mathrm{Na}$ Odsjeku za povijest umjetnosti Igor Fisković vodio je Katedru za srednjovjekovnu umjetnost od 1982., koju je vremenom širio mladim istraživačima, a sve do odlaska u mirovinu 2014. godine predavao niz kolegija iz užeg područja kasnosrednjovjekovne umjetnosti općeg i nacionalnog smjera. Bio je mentor četrdesetak magistranata i doktoranata, više puta pročelnik Odsjeka ili voditelj poslijediplomskih studija. Ujedno je kao predavač pomogao osamostaljivanju srodnih studija na fakultetima u Rijeci 1982.-1986., od 2003. u Dubrovniku i Mostaru, kao i na Likovnoj Akademiji u Zagrebu, i Splitu. Pri Internacionalnom centru za poslijediplomske studije u Dubrovniku od 1976. predavao je na tečaju "Kultura Jadrana", kojemu je od 1980. do 1983. bio i voditeljem. Uključen je u specijalističke i doktorske studije Medievistike i Kroatistike matičnog fakulteta i Međunarodnog centra hrvatskih sveučilišta za poslijediplomske studije u Dubrovniku. U sklopu suradnje s odjelom za urbanizam zagrebačkog Arhitektonskog fakulteta, uz sudjelovanje pri stvaranju prostornih planova za više primorskih i otočkih općina, predavao je na ljetnim školama hrvatskih i stranih studenata.

Znanstvenu je karijeru Igor Fisković izgradio kao vanjski suradnik Instituta za povijest umjetnosti od 1964., otkad je počeo samostalna istraživanja i redovito objavljivati znanstvene studije. Nećemo ovdje ući u detalje njegovih publikacija (bibliografija slijedi iza ovog teksta), nego samo naglasiti neke od tema u kojima je značajnije pomakao znanstvene spoznaje i zadužio našu struku. Osobito je doprinio projektima valorizacije spomenika likovnih umjetnosti kao i razrade urbanističkograđevnog nasljeđa u planovima prostornog uređenja Hrvatske, unutar programa Instituta za povijest umjetnosti i srodnih ustanova iz Zagreba, Dubrovnika i Splita. Vodio je arheološka iskopavanja u dubrovačko-neretvanskoj županiji, bavio se topografijom spomenika obalnih predjela, posebice otkrivajući ranokršćanski sloj u vangradskim prostorima. Istraživao je genezu i tipološku rasprostranjenost srednjovjekovne arhitekture, kulturološke i sociološke osnove regionalnog razvoja stilova od predromanike do manirizma, kao i urbanističke te ikonološke teme. Uz interdisciplinarni pristup napisao je sintezne tekstove o likovnoj kulturi pojedinih razdoblja ili prostornih zona i urbanih središta, a jača zanimanja zadržavao je u području južne Dalmacije te posebice Dubrovnika i Dubrovačke Republike. Kulturnu i umjetničku baštinu tog područja cjelovito je i sustavno istraživao sve do ranog modernog doba, ostvarujući zapažene i vrijedne rezultate iz povijesti graditeljstva, slikarstva i kiparstva. Ponajviše je izučavao staro kiparstvo primorja od Istre do Boke kotorske, s naglaskom na zrelom srednjem vijeku i renesansi, uz analitičke studije s interpretacijama sadržaja te atribucijama i utvrđivanjem datacija brojnih djela. Valja istaknuti kako je Igor Fisković objavio prve cjelovite preglede gotičkog i renesansnog kiparstva, te romaničkog slikarstva Hrvatske, kao i nekolicinu prigodnih prikaza umjetnosti humanističkog doba od 14. do16. stoljeća. Među inima ističe se 


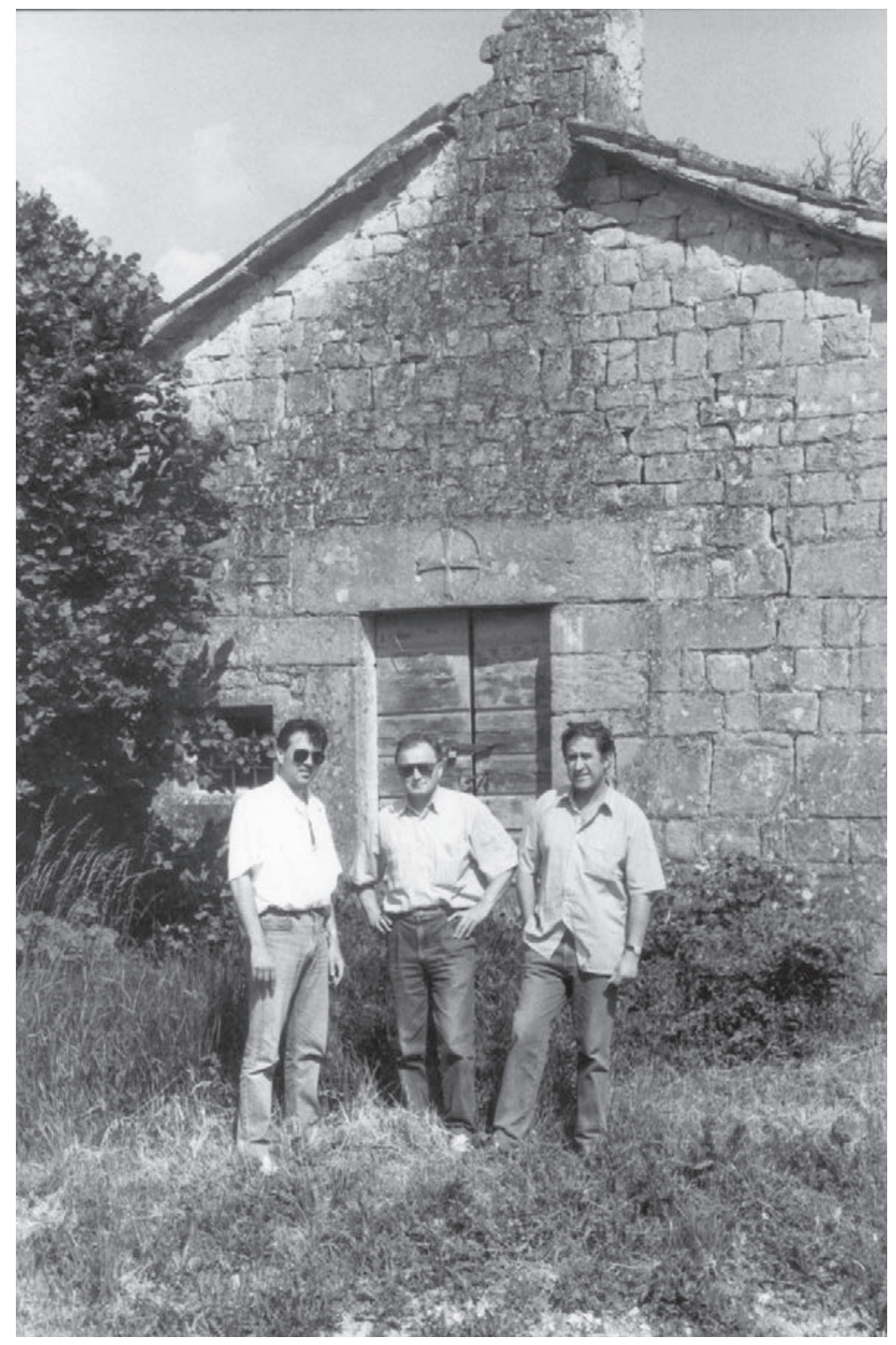

Slika 1. Na istarskom terenu, sa Ivanom Tenšekom i Miljenkom Jurkovićem krajem osamdesetih

Fig. 1. In Istria with Ivan Tenšek and Miljenko Jurković in late eighties

njegov široki i sveobuhvatni pregled likovne kulture jadranskog podneblja u povijesnom kontekstu 11. st. koji je objavljen u knjizi "Reljef kralja Petra Krešimira IV". U našu je povijest umjetnosti uveo i neka značajna imena (npr. otkriće kipara Jurja Petrovića iz 15. st.), proširio opuse najznamenitijih umjetnika, u prvom redu Jurja Matejeva Dalmatinca i Nikole Ivanova Firentinca. Posebice je pažnju posvećivao fenomenima odraza ranohumanističkih ideja u figuralnim umjetnostima, s naglaskom na literarnim izvorima i društtvenim okolnostima njihova usvajanja i širenja, proširujući često metodološke i teorijske osnove plastičkog stvaralaštva starijih razdoblja (posebno vrijedni tekstovi okupljeni su u knjizi "Reljef renesansnog Dubrovnika). Temeljem arhivske građe i likovne analize izučavao je veze Dalmacije s Italijom i Mađarskom, te Bosnom i Srbijom, djelatnost starih hrvatskih umjetnika izvan granica domovine (monografski je obradio djelatnost Jurja Dalmatinca u Ankoni, te proširio opus Ivana Duknovića u Rimu i Laziu), a jednakim je intenzitetom proučavao i djelovanje stranih kipara i graditelja 14.-16. st. na istočnoj obali Jadrana (Jakov de Spinis iz Orléansa). U istraživačkome radu vodio je niz znanstvenih projekata, neke s većim brojem suradnika, kao "Umjetnost na istočnoj obali Jadrana od XI do XVI st.", pa i međunarodnog značaja kao "Umjetnička baština Istre od IV do XIV 
st." do 1990., "Umjetnost gotičkog doba na tlu Bosne i Hercegovine" za Sveučilište u Mostaru 2002. g. Od 2006. do 2013. pri Ministarstvu znanosti RH bio je na čelu interdisciplinarnog programa "Srednjovjekovni i renesansni identitet Hrvatske u europskom kontekstu".

Svoja je istraživanja Igor Fisković prezentirao na mnogim znanstvenim skupovima, međunarodnima u Hrvatskoj i izvan nje (Venecija, Firenza, Rim, Ancona, Siena, Osimo, Rimini, Siracusa, Amsterdam, London, York, Budapest, Clermont Ferrand, Los Angeles), te još brojnijim domaćima od kojih je neke organizirao kao voditelj ili član odbora. Osim studijskih boravaka u inozemstvu (Italija, Njemačka, Francuska) po pozivu je 1986. održao seriju predavanja o starijoj hrvatskoj umjetnosti u SAD (Univ. Columbia, Yale, Princeton, Stanford, Berkeley, UCLA, Dumbarton Oaks ), potom dvije godine bio vanjski savjetnik (foreign adviser) Centra za srednjovjekovnu umjetnost u New Yorku - ICMA. Na polju izdavaštva Igor Fisković je uredio desetak zbornika znanstvenih radova, recenzirao je niz knjiga za više hrvatskih izdavača kao i dva znanstvena programa za strana Sveučilišta. Sastavio je pogovor prvom prijevodu "Civilizacija srednjovjekovnog Zapada" J. le Goffa. Surađivao je u djelatnosti "Śkolske knjige" s preglednim tekstovima u novim udžbenicima za srednjovjekovnu povijest, a također i u redakcijama izdanja HAZU "Hrvatska i Europa". Pri Leksikografskom zavodu "Miroslav Krleža" bio je vanjski urednik Likovne Enciklopedije Hrvatske I-II, a sada isto u Biografskom leksikonu, te u Hrvatskoj Enciklopediji, odnosno Likovnom Leksikonu. Član je uredničkih kolegija časopisa "Pasionska baština", "Peristil" i "Godišnjak za zaštitu spomenika" u Zagrebu, "Mogućnosti" u Splitu, te "Hortus Artium Medievalium".

Dugo primjenjujući svoja znanja i iskustva u konzervatorsko-restauratorskim poslovima, od 1992. do 1996. koordinirao je zaštitu i obnovu spomenika u ratom ugroženom području Dubrovnika, gdje je osnovao i prvu restauratorsku radionicu za pokretne umjetnine u regiji, te pokrenuo i edicije iste službe. Ostavio je traga pri uređivanju nekoliko muzeja i zbirki sakralne baštine od Krka do Korčule i Pelješca. Inače je trajno pridonosio popularizaciji nasljeđa posredstvom predavanja u kulturnim središtima i ustanovama, autor je TV serijala "Umjetnička baština Hrvatske" s tridesetak realiziranih filmova od 1985. do 2002. Inicirao je ili koordinirao vrlo značajne izložbe sintezne naravi poput: "Romaničko slikarstvo Hrvatske" (Zagreb - Split 1986.), "Tisuću godina hrvatske skulpture" ( Zagreb Dubrovnik 1991.), "Arte per mare" (San Marino 2007.), "Dominikanci u Hrvatskoj" (Zagreb 2008.), "Umjetnička baština franjevaca u Dalmaciji" (Zagreb 2011.) kao i samostalno više manjih : npr. "Muka Kristova u hrvatskoj likovnoj baštini" ( Muzej Mimara 1998.). Bio je članom stručnih ekipa i odbora za domaće izložbe "Juraj Dalmatinac" 1975., "Zlatno doba Dubrovnika" 1986., "Stoljeće gotike na Jadranu: slikarstvo u ozračju Paola Veneziana" 2004., te nekolicinu vanjskih: "Hrvati: kršćanstvo, kultura, umjetnost" za Vatikan 1999., "Anžuvinci i Europa" za Francusku 2001., "Umjetnička blaga Hrvatske" 2001. za Italiju, te "Hrvatska Renesansa" za Francusku (Ecouen - Zagreb 2004.).

$\mathrm{Na}$ širem stručnom polju je obnašao dužnosti u strukovnim i znanstvenim ustanovama od člana Izdavačkoga savjeta ili potpredsjednika Društva povjesničara umjetnosti Hrvatske, Savjeta za zaštitu spomenika kulture Hrvatske 1987.-90., Savjeta Muzejsko-galerijskog centra u Zagrebu 1988.-92., Upravnog odbora Instituta za povijest umjetnosti 1994.-98., od 2005. kao višegodišnji predsjednik, te istog odbora Instituta za arheologiju u Zagrebu 1996.-1999., Odbora zaklade "Otvoreno društvo" za Hrvatsku 1995-98., ravnateljstva Hrvatskog Povijesnog Muzeja Hrvatske 1991.-2002., ICOMOS odbora za Hrvatsku od 1997., ili UNESCO-ova povjerenstva za istu problematiku. Bio je član ili predsjednik Matične komisije za povijesne znanosti zagrebačkog Sveučilišta u više mandata. Djelovao je unutar znanstvenih odbora i tijela sazivača niza simpozija, posebno organizirajući jedini strukovni znanstveni skup u našoj zemlji ("Dani Cvita Fiskovića" I-XIV). Trajno je član Znanstvenog savjeta Međunarodnog istraživačkog centra u Motovunu kao jedan od utemeljitelja ustanove od 1993.godine. Od 1987. stalni je član Stručno-savjetodavne komisije za obnovu Dubrovnika, 1998-2001., Povjerenstva za zaštitu i očuvanje kulturnih dobara pri Ministarstvu kulture RH., a sada obnaša dužnost predsjednika Vijeća za kulturna dobra. Na temelju njegova elaborata grad Korčula je 2007. upisan 


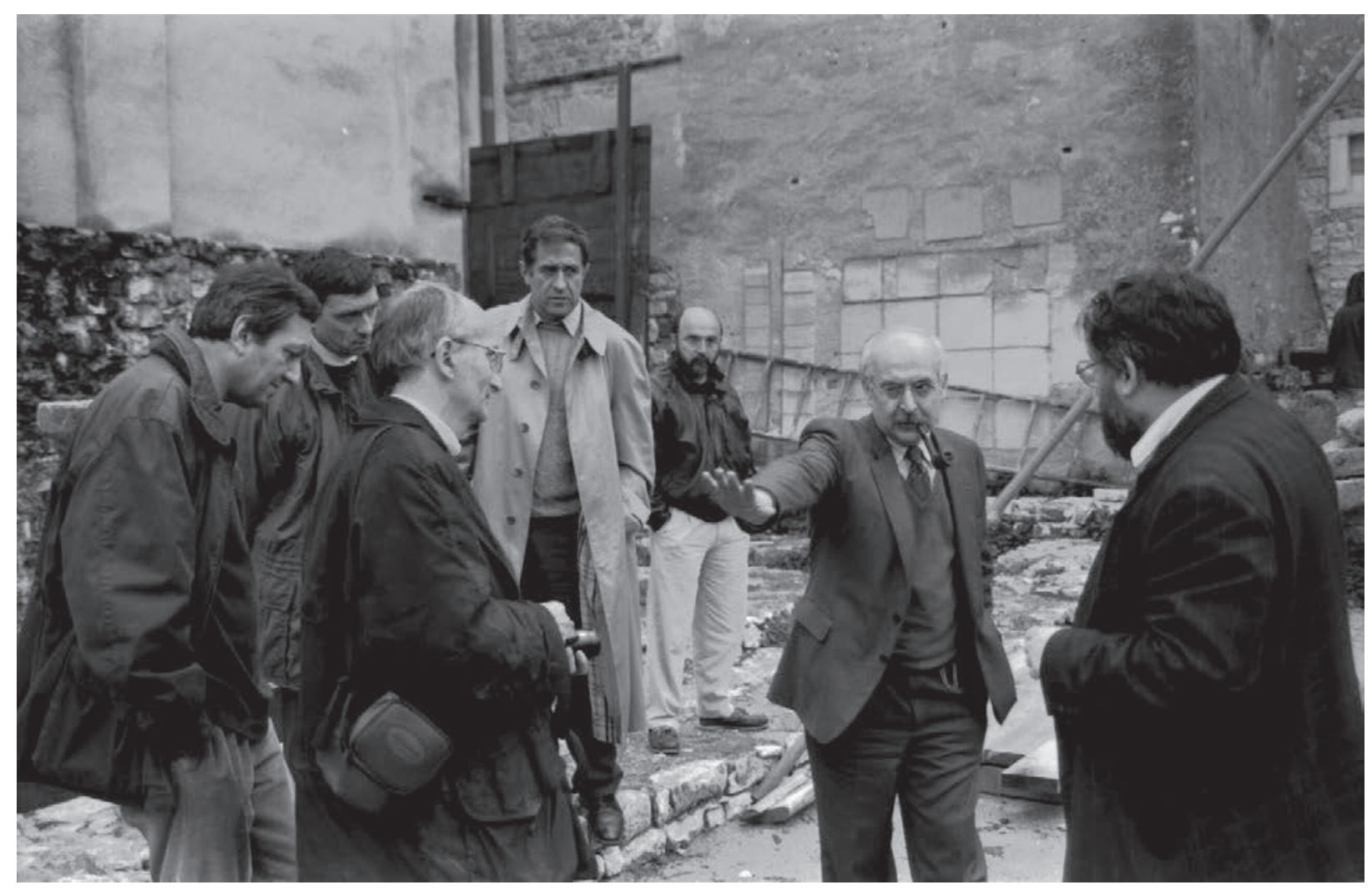

Slika 2. Poreč, ekskurzija prvog simpozija MICa, 1994. (s lijeva na desno: Jean-Pierre Caillet, Nikola Jakšić, Jean- François Reynaud, Igor Fisković,..., Fulvio Zuliani, Ivan Matejčić

Fig. 2. Poreč, field trip of the first IRCLAMA colloquium (from left to right: Jean Pierre Caillet, Nikola Jakšić, Jean François Reynaud, Igor Fisković,..., Fulvio Zuliani, Ivan Matejčić

u Tentativnu listu Svjetske baštine pod zaštitom UNESCO-a. Član je stručnih udruga: Društvo povjesničara umjetnosti Hrvatske i Hrvatsko arheološko društvo, Association pour l'antiquité tardive, ULUPUH - sekcija kritičara.

Za dugogodišnji plodan znanstveni rad Igor Fisković primio je više priznanja. God. 1987. primio je Nagradu "Božidar Adžija" za znanstveni rad, pa Povelju Orebića i Povelju Filozofskog fakulteta, Nagradu "J. J. Strossmajer", a 2004. je dobio odličje "Hrvatska Danica s likom Marka Marulića". U proljeće 2004. izabran je za redovnog člana Hrvatske Akademije znanosti i umjetnosti u stalnom radnom sastavu - djelujući kao voditelj Grafičkog kabineta i član više odbora njezinih ustanova, a 2011. dobio je Nagradu za životno djelo Županije dubrovačko-neretvanske. 


\section{Biographical note}

Igor Fisković was born in Orebići on Pelješac peninsula on April 23, 1944, in an old seamen's home surrounded with gardens that subsequently became protected by the state as a unique cultural and historic heritage site. Mother Linda studied painting and father Cvito was the most prominent Croatian art historian and for 40 years head of the Institute for the protection of cultural heritage of Dalmatia. Both the ambiance and the intellectual environment in which he grew up have deeply impacted his scientific career.

Igor Fisković graduated from Classical Gymnasium in Split. He studied art history and archaeology at the University of Zagreb (Faculty of Humanities and Social Sciences, then Faculty of Philosophy) and graduated in 1968. In 1975 he completed the doctoral program and received his Ph.D. Since 1970, he has been teaching at the Department of Art History, advancing from associate professor (1979), to scientific advisor (1984) and full professor (1985). Beginnings of his career are associated with the leading authorities on humanities who were instrumental in developing art history study program, such as Milan Prelog, Grgo Gamulin and Vera Horvat Pintarić. Their crucial contributions to methodology have left a significant and lasting mark on the Fisković's entire generation.

From 1982 to his retirement in 2014, Igor Fisković held the Chair of Medieval Art at the Department of Art History, expanding it through the years with young researchers. He taught several courses on national and European Late Medieval art, supervised some 40 master's and doctoral theses and served several terms as head of Department and postgraduate program chair. In his capacity as teacher Igor Fisković helped develop related study programs at the universities of Rijeka (1982 - 1986), Dubrovnik and Mostar (since 2003), as well as at the Academy of Fine Arts in Zagreb and Split. From 1976, Fiskovic was one of the lecturers in the course "Culture of the Adriatic", organized by the International Center for Advanced Studies in Dubrovnik (from 1980 to 1983 he acted as chair). He is involved in specialist and doctoral programs in Medieval studies as well as Croatian studies at the Faculty of Humanities and Social Sciences in Zagreb and at the Interuniversity Center (International Center for Advanced Studies) in Dubrovnik. As part of his cooperation with the Department of urban design at the Faculty of Architecture in Zagreb he participated in physical planning of several coastal and island communities and taught at summer schools for Croatian and foreign students.

Igor Fisković began his scientific career as adjunct researcher at the Institute of Art History (in 1964), which coincides with his first independent research activities and published scientific studies. Since this text is followed by a full bibliography we will not analyze his publications in detail; instead we will focus on some of the topics with which he expanded scientific knowledge and indebted the field of art history. Fisković's particular contribution is manifested in the projects of valorization of fine arts monuments as well as in thorough analysis of urban and building heritage in Croatian urban and physical planning, carried out under the auspices of the Institute of Art History and similar institutions in Zagreb, Dubrovnik and Split. He was in charge of archaeological excavations in the Dubrovnik-Neretva County and worked on monument topography of coastal regions, with particular emphasis on early Christian layers in areas outside of urban settlements. He studied the genesis and typological distribution of medieval architecture, cultural and sociological bases of regional styles from Late Antiquity to manneristic period, as well as urban and iconological topics. He has written interdisciplinary synthetic texts on art through different periods or areas and urban centers, focusing on south Dalmatia and in particular on Dubrovnik and the Dubrovnik Republic. Fisković researched cultural and artistic heritage of that area comprehensively and systematically up to the early modern period and obtained impressive and valuable results related to the history of building, painting and sculpture. His focus has been on the old sculpture of the littoral, from Istria to the Bay of Kotor, with particular emphasis on the late Middle Ages and Renaissance. The work included analytical studies with content interpretation as well as attributing and dating numerous pieces of art. Igor Fisković published first comprehensive reviews of gothic and renaissance sculpture as well 


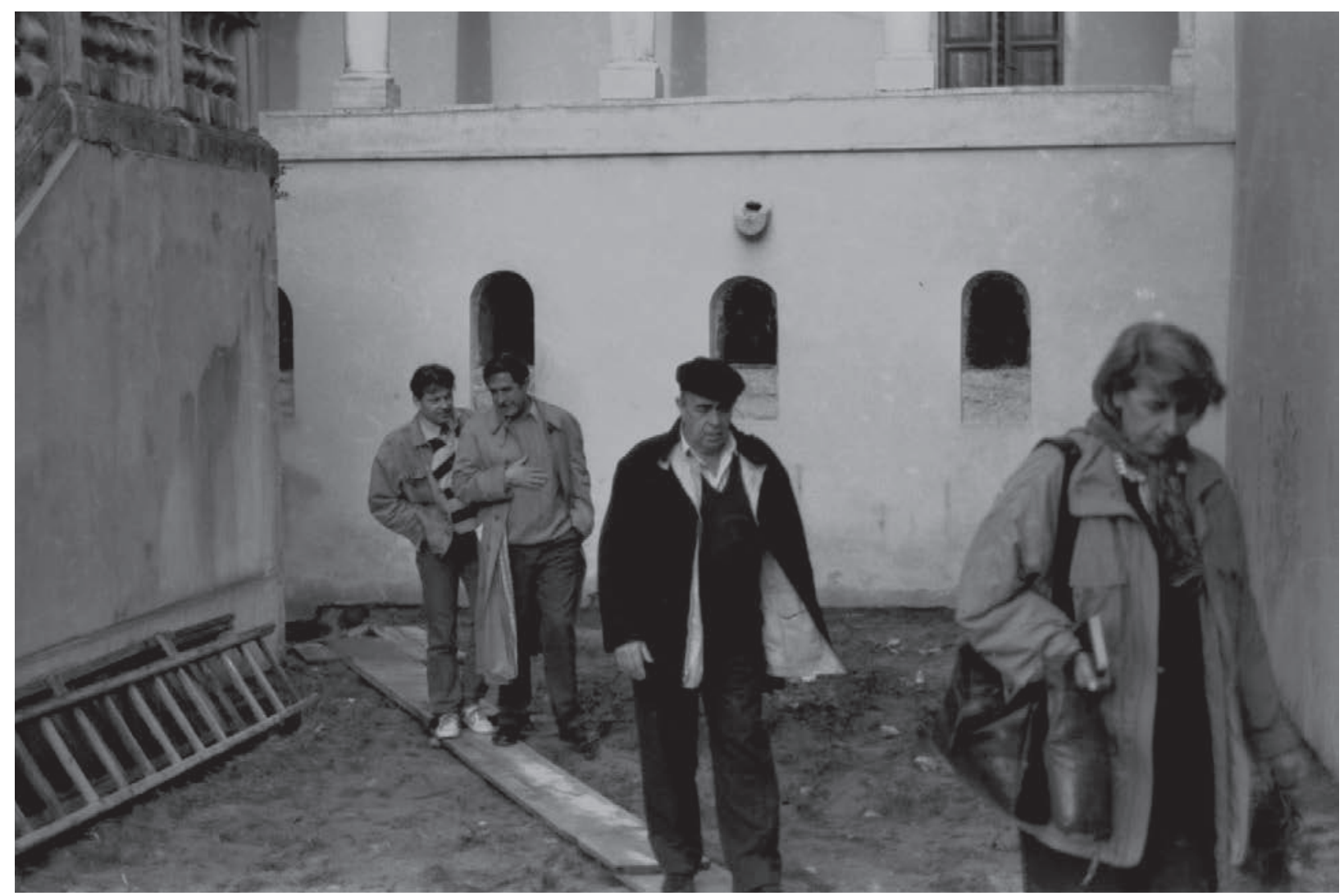

Slika 3. Poreč, Eufrasijana, 1994: Gabrijela Vidan, Željko Rapanić, Igor Fisković, Miljenko Jurković Fig. 3. Poreč, Cathedral complex, 1994: Gabrijela Vidan, Željko Rapanić, Igor Fisković, Milienko Jurković

as Romanesque painting in Croatia, and several occasional reviews of arts during the $14^{\text {th }}-16^{\text {th }}$ centuries humanistic period. Among others, stands out his elaborate and comprehensive review of art in the Adriatic region during $11^{\text {th }}$ century, published in the book Reljef kralja Petra Krešimira IV. He introduced some important names to Croatian art history (e. g. 15 th century sculptor Juraj Petrović) and expanded the works of the best known artists, primarily Juraj Matejev Dalmatinac and Nikola Ivanov Firentinac. He paid particular attention to the reflections of early humanistic ideas in figural arts, with emphasis on literary sources and social circumstances of their acceptance and spreading, frequently expanding methodological and theoretical bases of plastic creation of older periods (particularly valuable texts have been compiled in the book Reljef renesansnog Dubrovnika). By means of archival records and analysis he studied the connections of Dalmatia with Italy and Hungary as well as Bosnia and Serbia, the activity of old Croatian artists abroad (Juraj Dalmatinac in Ancona and Ivan Duknović) and with equal intensity he researched the work of foreign sculptors and builders in the period between the $14^{\text {th }}$ and $16^{\text {th }}$ centuries on the east Adriatic coast (Jakov de Spinis from Orléans).

Igor Fisković conducted a series of scientific projects: some involved a considerable number of collaborators, such as "Umjetnost na istočnoj obali Jadrana od XI do XVI st.", and were internationally acknowledged, such as "Umjetnička baština Istre od IV do XIV st." (until 1990) and "Umjetnost gotičkog doba na tlu Bosne i Hercegovine" (University of Mostar, 2002). Between 2006 and 2013 he was principal investigator in the Croatian Ministry of Science interdisciplinary program "Srednjovjekovni i renesansni identitet Hrvatske u europskom kontekstu".

Igor Fisković presented his work at numerous international scientific conferences, both in Croatia and abroad (Venice, Florence, Rome, Ancona, Siena, Osimo, Rimini, Siracusa, Amsterdam, London, York, Budapest, Clermont Ferrand, Los Angeles), and at many national ones, some of which he organized in the capacity of president or member of organizing committees. Apart from travel studies abroad (Italy, Germany, France), he was invited to present a series of talks on older Croatian art in 
the United States (University of Columbia, Yale, Princeton, Stanford, Berkeley, UCLA, Dumbarton Oaks) and was subsequently engaged as foreign adviser at the International Center of Medieval Art in New York - ICMA. Igor Fisković has been very active in publishing as well. He edited a dozen proceedings, peer-reviewed a series of books for Croatian publishers and two research programs for universities abroad. He wrote the preface to the first translation of J. le Goff's Medieval Civilization ("Civilizacija srednjovjekovnog Zapada"). He also cooperated with the publisher "Školska knjiga", contributing review chapters in new textbooks on medieval history, and with Croatian Academy of Sciences and Arts on editions of "Hrvatska i Europa". He was adjunct editor of Likovna Enciklopedija Hrvatske I-II (Croatian Encyclopaedia of Visual Arts I-II) at the "Miroslav Krleža" Institute of Lexicography and remains their associate on Biografski leksikon (Croatian Biographical Lexicon), Hrvatska enciklopedija (Croatian Encyclopaedia) and Likouni leksikon (Lexicon of Fine Arts). He serves on the editorial board of journals"Pasionska baština", "Peristil" and "Godišnjak za zaštitu spomenika" in Zagreb, "Mogućnosti" in Split and "Hortus Artium Medievalium".

After years of application of his expertise and experience in conservation and restoration, in the period between 1992 and 1996, Igor Fisković coordinated protection and restoration of monuments in the war endangered Dubrovnik area, where he established the region's first artworks restoration unit and initiated relevant publications. He left an indelible trace in the organization of several museums and collections of sacral heritage from Krk to Korčula and Pelješac. Over the years he has continuously contributed to the popularization of heritage by giving talks in various cultural venues and institutions. Between 1985 and 2002, he authored TV series "Umjetnička baština Hrvatske" comprising some 30 films. He initiated or coordinated important synthetic exhibitions such as "Romaničko slikarstvo Hrvatske" (Zagreb - Split 1986), "Tisuću godina hrvatske skulpture" (Zagreb - Dubrovnik 1991), "Arte per mare" (San Marino 2007), "Dominikanci u Hrvatskoj" (Zagreb 2008), "Umjetnička baština franjevaca u Dalmaciji" (Zagreb 2011), as well as, independently, several smaller ones, e. g. "Muka Kristova u hrvatskoj likovnoj baštini" (Muzej Mimara 1998). He was a member of expert teams and organizing committees of national exhibitions "Juraj Dalmatinac" (1975), "Zlatno doba Dubrovnika" (1986), "Stoljeće gotike na Jadranu: slikarstvo u ozračju Paola Veneziana" (2004), and several others that were organized abroad: "Hrvati: kršćanstvo, kultura, umjetnost" (Vatican, 1999), "Anžuvinci i Europa" (France, 2001), "Umjetnička blaga Hrvatske" (Italy, 2001) and "Hrvatska Renesansa" (France: Ecouen - Zagreb, 2004).

Igor Fisković served on many professional and scientific boards and committees: member of editorial council and vice-president of Croatian Society of Art Historians, Council for the protection of cultural heritage (1987 - 1990), Steering committees of the Museum and Gallery Center in Zagreb (1988 - 1992), and of the Institute of Art History (1994 - 1998), since 2005, several terms as president, Steering committee of the Institute of Archaeology in Zagreb (1996 - 1999), Board of the Croatian branch of the Open Society Foundation (1995 - 1998), Board of Croatian History Museum (1991 1992), ICOMOS committee for Croatia (since 1997) and UNESCO committee for monuments and sites. He was active in scientific and program committees of several symposia, particularly in the organization of the only national scientific conference on art history "Dani Cvita Fiskovića" (I-XIV). Igor Fisković is permanent member of the scientific council of the International Research Center in Motovun, as one of the founders of the institution since 1993. He has also been permanent member of the Expert Advisory Board for Restauration of Dubrovnik (since 1987) and was a member of the Commission for the protection and preservation of cultural heritage of Croatian Ministry of Culture $(1998$ - 2001). At the moment, he is president of the Council for cultural heritage. Based on Fisković's study, the town of Korčula was included in the Tentative list of UNESCO world heritage sites in 2007. He is member of professional associations: Društvo povjesničara umjetnosti Hrvatske (Croatian Society of Art Historians) and Hrvatsko arheološko društvo (Croatian Archaeological Society), Association pour l'antiquité tardive and ULUPUH - (Croatian Association of Artists of Applied Arts - Department for art criticism, art history and theory of art). 
Igor Fisković received several awards for his long and fruitful scientific work. In 1987, he was awarded "Božidar Adžija" for his contribution to science, the award of the town of Orebić (Povelja Orebića), the life achievement award of the Faculty of Humanities and Social Sciences (Povelja Filozofskog fakulteta) and the "J. J. Strossmajer". In 2004, he was decorated by the Republic of Croatia with "Order of Danica Hrvatska Marko Marulić" for culture ("Hrvatska Danica s likom Marka Marulića"). In spring 2004 he was elected full member of Croatian Academy of Sciences and Arts, and has been active as head of the Department of Prints and Drawings and member of several committees of affiliated institutions. In 2011, Igor Fisković received the life achievement award from the Dubrovnik-Neretva County. 